\title{
ЗАБЕЗПЕЧЕННЯ ПОЗОВУ: СПІВВІДНОШЕННЯ ДОКТРИНАЛЬНИХ ПОЛОЖЕНЬ ТА ПРАКТИЧНОЇ ДІЯЛЬНОСТІ
}

\begin{abstract}
Анотація. Статтю присвячено дослідженню окремих теоретичних поло-жень у частині тлумачення поняття «забезпечення позову». Проаналізовано окремі доктринальні доробки вчених дореволюційних та радянських часів, а також з'ясовано напрям сучасного вектору розвитку наукових теорій та виявлено їх системні недоліки, зокрема залишення поза увагою важливих характеризуючих ознак та використання неюридичної термінології, що потребує додаткового тлумачення. Виявлено тенденцію до звуженого розуміння кола суб'єктів, які в силу положень цивільного процесуального закону наділені правом звертатись до суду із заявою про забезпечення позову. Встановлено невідповідність деяких теоретичних положень з окресленої тематики приписам чинного законодавства. На прикладах поточної судової практики доведено, що заходи забезпечення позову мають двояку спрямованість. За результатами проведеного дослідження запропоновано власне авторське визначення терміну «забезпечення позову» 3 урахуванням його основних змістовних характеристик, а також сформульовано пропозицію щодо удосконалення положень Цивільного процесуального кодексу України.
\end{abstract}

Ключові слова: поняття «забезпечення позову», теорія та практика, двояка спрямованість, суб’єкти подання заяви про забезпечення позову, удосконалення законодавства.

Prytyka Yuriy, Alendar Yuliia Taras Shevchenko National University of Kyiv

\section{SECURING THE CLAIM: CORRELATION BETWEEN DOCTRINAL STATEMENTS AND PRACTICAL ACTION}

Summary. Nowadays the institution of securing the claim is an integral com-ponent of the mechanism designed for promoting the effective administration of civil justice, guaranteeing the achievement of civil proceedings' objectives, preserving the balance of rights and interests of the parties. The lack of thorough research on the outlined topic (last comprehensive research was presented in 2012), legislative changes introduced in 2017 determine the relevance of this study. As it was found, today the legal doctrine has not developed a common approach to understanding its basic essence. The article analyzes theoretical provisions related to interpretation the concept "securing the claim" and outlines its advantages and disadvantages. Some doctrinal works of pre-revolutionary and Soviet times were analyzed, as well as the directions of the modern scientific theories' development. As a result, the main systemic shortcomings were revealed, in particular, neglecting important characteristics and usage of non-legal (plain) terminology. Such omissions cause necessity in additional interpretation in case of practical application of securing of the claim. The article also indicates a tendency to a limited interpretation of the subjects' range, which are entitled to apply to the court for securing the claim. In legal doctrine, just like in Civil Procedure Code of Ukraine, only plaintiffs are usually mentioned as the initiating party of this issue. But comparative analysis of legislative provisions have shown, that in this context the defendants and third parties with independent claims on the claim' subject are also should be named. The inconsistency of theory with the requirements of the current legislation has been established. The current case law has shown that measures of securing a claim have a dual focus, which depends on the type of connection between the object and the claim. According to the results of the study, the author's own definition of the term "securing the claim" is proposed, taking into account its main content characteristics. The way of improving the rules of the Civil Procedure Code of Ukraine were suggested.

Keywords: the concept of "securing the claim", theory and practice, dual orientation, the initiating party of filing a statement of claim security, legislation's im-provement.

$\Pi$ остановка проблеми. Частиною 1 статті 2 ЦПК України проголошено основне завдання цивільного судочинства, задля досягнення якого необхідно, аби весь закріплений чинним законодавство механізм цивільного судочинства працював злагоджено та послідовно, сприяючи дотриманню основоположних принципів правосуддя. За таких умов важливого значення набувають забезпе-чувальні інститути, одним із яких $є$ інститут забезпечення позову, однак в пра-вовій доктрині не вироблено єдиного усталеного підходу щодо розуміння його змісту та сутності, запропоновані теоретичні концепщіі не в повній мірі відображають змістовні характеристики цього правового явища, a іноді вступають у суперечності із положеннями цивільного процесуального закону.
Аналіз останніх досліджень і публікацій. Окремі теоретичні та практичні проблеми досліджуваної тематики були висвітлені у наукових доробках вчених-процесуалістів О. Белікова, В.В. Корольова, О.О. Грабовської, К. Головко, О.С. Захарової, Д.Д. Луспеника, Є.I. Фурси, С.Я. Фурси та інших. Також було здійснено достатню кількість грунтовних дисертаційних досліджень, де окресленій проблематиці було приділено належну увагу. Так, I.А. Воробйовою вивчалось питання забезпечення цивільного позову на стадії досудового розслідування; дисертаційних досліджень Г.Є. Прусенко та М.С. Дев'яткіної розкрито проблематику вжиття державними судовими органами забезпечувальних заходів, у тому числі й заходів щодо 
забезпечення позову, на підтримку міжнародного комерційного арбітражу. Також інституту забезпечення позову було присвячено окремі підрозділи у роботах цивільних процесуалістів О.Ю. Одосій та О.С. Снідевича. Дослідження, присвячене виключно проблематиці забезпечення позову у цивільному процесі України, було здійснено Г.С. Бугою: «Забезпечення позову в цивільному процесуальному праві України» (2012 рік), однак з огляду на запровадження до ЦПК України значної кількості новел під час прийняття нової редакції 2017 року, вбачається за необхідне переосмислення та актуалізація наявних позицій та пошук шляхів удосконалення правового регулювання, що може стати базою для комплексного дослідження цього інституту 3 урахуванням сучасних правових реалій.

Виділення не вирішених раніше частин загальної проблеми. Аналіз наявних інформаційних джерел свідчить про відсутність єдиного підходу до використовуваної термінології, до того ж часто залишаються поза увагою ті чи інші невід'ємні специфічні ознаки забезпечення позову, що зумовлюе необхідність подальших наукових пошуків стосовно визначення поняття «забезпечення позову». Наразі відсутність кореляційного аналізу теоретичних напрацювань та відповідної практичної діяльності (зокрема законодавчо врегульованих процесуальних механізмів та поточної судової практики щодо розгляду заяв про забезпечення позову), призводить до того, що деякі доктринальні категорії та пропозиції внаслідок їх проектування в емпіричну площину виявляються нежиттездатними. Поза увагою науковців перебуває питання щодо можливості удосконалення чинного законодавства в частині зазначення суб'єктів, яких процесуальний закон наділяе правом звертатись до суду із заявою про застосування заходів забезпечення позову.

Мета статті. Головною метою ціеї роботи є вироблення власного автор-ського визначення поняття «забезпечення позову»; розроблення пропозиції по удосконаленню нормативно-правового регулювання інституту забезпечення позову.

Виклад основного матеріалу. Однією із основних причин активної наукової дискусії навколо визначення поняття забезпечення позову видається відсутність чіткого нормативно закріпленого визначення, а позиція законодавця щодо змістовного наповнення даного терміну простежується виключно через системний аналіз положень цивільного процесуального закону. Одним із сталих і часто застосовуваних на практиці визначень наведено у пункті 9 Постанови Пленуму Верховного Суду України від 22.12.2006 року «Про практику застосування судами цивільного процесуального законодавства при розгляді заяв про забезпечення позову» забезпечення позову визначається як сукупність процесуальних дій, які гарантують виконання рішення суду в разі задоволення позовних вимог» [1]. Відповідно до науково-практичного коментаря (2010 року) «забезпечення позову - це сукупність процесуальних дій, які гарантують виконання рішення суду в разі задоволення позовних вимог» [2, с. 294-295]. Однак, наведені тлумачення не можна сприймати як единовірні, 3 огляду на недосконалість та надто звужене ро- зуміння забезпечення позову, яке за своєю суттю має набагато складнішу правову природу. Разом 3 тим вони слугуватимуть відправною точкою для подальшого наукового пошуку за визначеним вектором.

Дослідження правової природи забезпечення позову розпочалось ще в дореволюційні часи. Так, за енциклопедичним словником Ф.А. Брокгауза та I.A. Ефрона забезпечення позову це «прийняття судом тимчасових охоронних заходів, що гарантують матеріальне здійснення грошових або інших вимог позивача по відношенню до відповідача, на випадок присудження цих вимог» [3]. Аналогічні підхід спостерігається і у працях I.M. П'ятилетова, який забезпечення позову визначає як «процесуальну дію судді або суду щодо прийнятого до розгляду і вирішення справи, викликане необхідністю застосування передбачених законом заходів, коли їх неприйняття може привести до неможливості виконання ухваленого в подальшому рішення про присудження, що вступило в законну силу» [4, с. 270]. У свою чергу М.А. Гурвич під забезпеченням позову розуміє вказані в законі заходи, прийняті судом на вимогу позивача, прокурора або з власної ініціативи, що мають на меті забезпечити виконання рішення суду, якщо таке рішення буде ухвалено [5, с. 170-171].

У наведених підходах спостерігається екстраполяція заходів забезпечення позову на стадію фрактичного виконання ухваленого рішення, тобто за мету їх застосування визначається саме забезпечення виконання рішення, а не забезпечення позову як матеріально-правової вимоги та/або немайнової (або їх сукупності). Більш того до суб'єктів, які вправі ініціювати питання про вжиття заходів забезпечення позову безпідставно віднесено суд (суддю), і залишено поза увагою осіб, що наділені правом звертатись до суду із відповідною заявою. Допускаємо, що ці своєрідні визначення терміну "забезпечення позову» певною мірою зумовлені особливостями правової системи того часу: декларативний характер основоположних принципів цивільного процесу (у тому числі й диспозитивності, рівності сторін перед законом і судом); формальний характер судочинства, де порядок розгляду і вирішення спірних правовідносин перш за все визначався загальнонаціональною доктриною, а не принципами верховенства права і законності; роль суду у правосудному процесі здебільшого визначалась як слідчого, а не незалежного, неупередженого, об'єктивного арбітра.

Разом з тим слід зауважити, що висловлювались й дещо інші позищії. Наприклад на думку К.Н. Анненкова, забезпечення позову - це прийняття різного роду охоронних заходів, що допускаються законом на прохання зацікавленої сторони, в більшості випадків позивача, але іноді і відповідача, коли він є зустрічним позивачем, заходів щодо майна відповідача з метою попереднього гарантування відповідній стороні справи в подальшому мати можливість отримати реальне задоволення своїх вимог за рахунок іншої сторони [6, с. 128]. У даному випадку обгрунтовано наголошено саме на попередньому характері такої процесуальної гарантії, а словосполучення «мати можливість» дуже влучно підкреслює імо- 
вірнісний характер такої попередньо гарантованої можливості. Крім того дослідник конкретизуе суб'єктів подання відповідної заяви.

Як відомо, юридична профресійна мова характеризуеться високим ступенем формалізму, визначеності та передбачає максимально можливе уникнення використання термінології, яка може бути розтлумачена двозначно, або значення якої потребує звернення до інших, ненормативних інформаційних джерел. 3 огляду на це невиправданим вбачається використання словосполучення "на прохання зацікавленої сторони», яке не відповідає усталеній лексикології викладення нормативно-правових положень, оскільки цивільне процесуальне законодавство не передбачає подання сторонами до суду «прохання». Аналогічну неточність допускає й Г.Л. Осокіна, вживаючи словосполучення "скрутне виконання рішення» [7, с. 485], яке також не підлягає однозначному розумінню, а тому для з'ясування істинного змісту використаного вислову необхідно додатково аналізувати довідкову та періодичну літературу.

Сучасний стан досліджень по окресленій проблематищі характеризуеться наявністю значної кількості наукових праць, де «забезпечення позову» тлумачиться одночасно за кількома напрямами:

- інститут цивільно-процесуального права;

- засіб захисту права й охоронюваного законом інтересу в суді;

- процесуальну гарантію, що забезпечує реальне виконання майбутнього судового рішення про задоволення позовних вимог;

- процесуальні дії щодо застосування судом передбачених законом заходів;

- заходи цивільного процесуального характеру, спрямовані на запобігання можливим утрудненням при виконанні рішення суду [8].

Ірунтовне дослідження еволющії наукових підходів до визначення поняття «забезпечення позову» було здійснено О.Ю. Одосій, за результатом чого авторкою зроблено висновок про, що «забезпечення позову - це вживання судом, у провадженні якого перебуває справа, необхідних заходів щодо охорони матеріально-правових інтересів позивача проти несумлінних дій відповідача, що гарантуе реальне виконання майбутнього судового рішення у випадку задоволення позовних вимог (повністю або частково)» $[9$, c. 62$]$. Із таким визначенням можна частково погодитись, але із кількома зауваженнями: по-перше, чинний ЦПК України уповноважуе позивача подати заяву про забезпечення позову до пред'явлення самого позову, відтак на момент постановлення ухвали про застосування заходу (заходів) процесуального примусу провадження у справі ще може бути не відкритим; по-друге, взагалі поза увагою залишаються ситуації, коли заходи забезпечення позову вживаються у межах підтримки, що в силу приписів законодавства може бути надана державними судами на підтримку міжнародного комерційного арбітражу, третейським судів шляхом вжиття окремих процесуальних дій; по-трете, знов таки стверджуеться, що такі заходи вживаються судом, але не зазначається, хто може звертатись до суду із відповідною заявою.
Отже, аналіз існуючих доктринальних підходів до визначення «забезпечення позову» продемонстрував, що надаючи визначення цього терміну науковців іноді не враховують окремі ознаки, використовують неюридичну лексику. При цьому переважна більшість або взагалі залишає поза увагою суб'єктний склад заявників, або значно його звужує, зазнаючи лише позивача, хоча положення чинного процесуального закону наділяють правом ініціювати здійснення заходів забезпечення позову може не лише позивача, а також й відповідача у випадку подання ним зустрічного позову, та третіх осіб, які заявляють самостійні вимоги на предмет спору - у даному випадку вони в силу приписів частини 3 статті 52 ЦПК України користуватимуться усіма права та обов'язками позивача, не змінюючи при цьому свого первісного процесуального статусу.

Такого обмеженого підходу дотримується й законодавець, зокрема частиною 2 статті 149 ЦПК України передбачено, що заходи забезпечення позову застосовуються задля захисту прав та інтересів позивача [10]. На думку авторів, наведене положення потребуе доопрацювання.

Аналіз теоретичних напрацювань в межах окресленої проблематики у порівнянні із напрацьованою судами практикою розгляду заяв про забезпечення позову дає достатні підстави для висновку, що ці заходи мають двоїсту спрямованість в залежності від об'єкта, відносно якого вони застосовуються, та його співвідношення із предметом позовної заяви. В одних випадках заходи забезпечення позову вживаються 3 метою створення попередньої матеріальної гарантії того, що ухвалене за результатом розгляду справи рішення буде виконане (хоча б частково). Наприклад, у справі № 686/29748/20 про повернення позики за розпискою Ухвалою Хмельницького міськрайонного суду Хмельницької області від 23.02.2020 року [11] було задоволено заяву про забезпечення позову шляхом накладення арешту на домоволодіння.

Тоді як переважна більшість позитивно розглянутих заяв про забезпечення позову стосується безпосередньо предмета позову. Так, у справі № 548/136/21 про визнання виконавчого напису таким, що не підлягає виконанню Ухвалою Хорольського районного суду Полтавської області від 09.02.2021 року [12] було забезпечено позов шляхом зупинення стягнення за цим виконавчим написом. В якості ще одного прикладу наведемо справу № 208/1496/21, відкриту за позовом про припинення речового права на нерухоме майно (підприемство громадського харчування з літнім майданчиком), де Ухвалою Заводського районного суду міста Дніпродзержинська Дніпропетровської області від 04.03.2021 року [13] було задоволено заяву про забезпечення позову шляхом заборони будь-яким суб'єктам державної реєстрації прав вчиняти реєстраційні дії в Державному реєстрі речових прав на нерухоме майно, Державному реєстрі іпотек, Єдиному реєстрі заборон відчуження на об'єкт нерухомого майна щодо майна, з приводу речового права на яке і виник спір, що став предметом судового розгляду.

Висновки і пропозиції. 3 огляду на результати проведеного дослідження можемо зробити висновок про досягнення поставленої мети. 3 ура- 
хуванням викладеного, пропонується під забезпеченням позову розуміти заходи, що вживаються судом за заявою сторони справи, уповноваженої на подання такої заяви в силу положень процесуального закону, чиї права можуть бути безпідставно порушені чи обмежені внаслідок несумлінних дій інших учасників справи або з метою створення попередньої гарантії того, що судове рішення, ухвалене за результатом розгляду справи по суті, реально буде виконане (хоча б частково).

3'ясовано, що під час тлумачення терміну «забезпечення позову» науковцями часто необгрунтовано звужується суб'єктний склад осіб (зазначається лише про позивача), які мають процесуальне право на подання до суду заяви про застосування заходів забезпечення позову.
Аналогічний підхід простежується й у законодавця, а тому з метою удосконалення нормативно-правового регулювання забезпечення позову у цивільному процесі України пропонуеться положення частини 2 статті 149 ЦПК України викласти у наступній редакції: «2. Забезпечення позову допускається як до пред'явлення позову, так і на будь-якій стадії розгляду справи, якщо невжиття таких заходів може істотно ускладнити чи унеможливити виконання рішення суду або едективний захист, або поновлення порушених чи оспорюваних прав або інтересів позивача, а також інших осіб, які відповідно до положень цього Кодексу користуються усіма правами та обов'язками позивача, за захистом яких вони звернулися або мають намір звернутися до суду»/

\section{Список літератури:}

1. Про практику застосування судами цивільного процесуального законодавства при розгляді заяв про забезпечення позову : Постанова Пленуму Верховного Суду України від 22.12.2006 року № 9. URL: http://zakon.rada.gov.ua/laws/show/va009700-06 (дата звернення: 29.03.2021).

2. Теліпко В.Е. Науково-практичний коментар Цивільного процесуального кодексу України. Станом на 01.11.2011 року / за ред. Притики Ю.Д. Київ : Центр учбової літератури, 2011. 696 с.

3. Энциклопедический словарь Ф.А. Брокгауза и И.А. Ефрона / Ф.А. Брокгауз, І.А. Єфрон. Санкт-Петербург, 1890-1907. URL: dic.academic.ru (дата звернення: 29.03.2021).

4. Семенов B.M. Советский гражданский процесс / В.М. Семенов; под ред. К.И. Комиссарова, В.М. Семенова. Москва, 1988. 480 с.

5. Гурвич М.А. Советское гражданское процессуальное право / под ред. Гурвича М.А. Москва, 1985.528 с.

6. Анненков К.Н. Опыт комментария к уставу гражданского судопроизводства. Санкт-Петербург, 1887. Т. 3.485 с.

7. Осокина Г.Л. Гражданский процесс. Общая часть. Москва, 2004. 704 с.

8. Денисов И.С. Институт обеспечения иска в российском гражданском и арбитражном процессе : дис. ... канд. юрид. наук. Санкт-Петербург, 2006. 176 с.

9. Одосій О.Ю. Еволюція наукових підходів щодо визначення поняття «забезпечення позову». Науковий вiсник Міжнародного гуманітарного університету : збірник наукових праць. Серія «Юриспруденція». Одеса. 2015. Випуск 17. Том 2. С. 59-62. URL: http://nbuv.gov.ua/UJRN/Nvmgu_jur_2015_17\%282\%29_17 (дата звернення: 22.03.2021).

10. Цивільний процесуальний кодекс України : Закон України № 1618-IV від 18.03 .2004 року. URL: https://zakon.rada.gov.ua/laws/show/1618-15\#Text (дата звернення: 22.03.2021).

11. Ухвала Хмельницького міськрайонного суду Хмельницької області від 23.02 .2020 року, судова справа № 686/29748/20. URL: https://reyestr.court.gov.ua/Review/95125752 (дата звернення: 28.03.2021).

12. Ухвала Хорольського районного суду Полтавської області від 09.02.2021 року, судова справа № 548/136/21. URL: https://reyestr.court.gov.ua/Review/95444558 (дата звернення: 28.03.2021).

13. Ухвала Заводського районного суду міста Дніпродзержинська Дніпропетровської області від 04.03.2021 року, судова справа № 208/1496/21. URL: https://reyestr.court.gov.ua/Review/95463078 (дата звернення: 28.03.2021).

\section{References:}

1. Pro praktiku zastosuvannya sudami civil'nogo procesual'nogo zakonodavstva pri rozglyadi zayav pro zabezpechennya pozovu: Postanova Plenumu Verhovnogo Sudu Ukraïni vid 22.12.2006 roku № 9 [About practice of application by courts of the civil procedural legislation at consideration of statements on maintenance of the claim: Resolution of the Plenum of the Supreme Court of Ukraine No. 9 of December 22, 2006]. Available at: http://zakon.rada.gov.ua/laws/show/va009700-06 (accessed 29 March 2021).

2. Telipko V.E., za red. Pritiki Y.D. (2011) Naukovo-praktichnij komentar Civil'nogo procesual'nogo kodeksu Ukraïni. Stanom na 01.11.2011 [Scientific and practical commentary on the Civil Procedure Code of Ukraine. As of 01.11.2011]. Kyiv: Centr uchbovoi literaturi, 696 p.

3. Brokgauz F.A., Efron I.A. (1890-1907). Enciklopedicheskij slovar' [Encyclopedic dictionary]. Available at: http://dic.academic.ru (accessed 29 March 2021).

4. Semenov V.M. (1988) Sovetskij grazhdanskij process [Soviet civil process]. Moscow, 1988, $480 \mathrm{p}$

5. Gurvich M.A. (1985) Sovetskoe grazhdanskoe processual'noe parvo [Soviet civil procedural law]. Moscow, 528 p.

6. Annenkov K.N. (1887) Opyt kommentariya k ustavu grazhdanskogo sudoproizvodstva [Experience of commenting on the charter of civil proceedings]. Sankt-Peterburg, vol. 3, $485 \mathrm{p}$.

7. Osokina G.L. (2004) Grazhdanskij process. Obshchaya chast' [Civil pro-ceedings. The general part]. Moscow, 704 p.

8. Denisov I.S. (2006) Institut obespecheniya iska v rossijskom gra-zhdanskom i arbitrazhnom processe [Institute for Inspection in the Russian Civil and Arbitration Process] (Candidate's thesis). Sankt-Peterburg, $176 \mathrm{p}$.

9. Odosij O.Y. (2015) Evolyuciya naukovih pidhodiv shchodo viznachennya ponyattya «zabezpechennya pozovu» [Evolution of scientific approaches to the definition of "securing a claim"]. Naukovij visnik Mizhnarodnogo gumanitarnogo universitetu: zbirnik naukovih prac'. Seriya "Yurisprudenciya». Odesa, vol. 17, no. 2, pp. 59-62. Available at: http://nbuv.gov.ua/UJRN/Nvmgu_jur_2015_17\%282\%29_17 (accessed 22 March 2021).

10. The Law of Ukraine (March 18, 2004) Civil'nij procesual'nij kodeks Ukraïni № 1618-IV [Civil Procedure Code of Ukraine № 1618-IV]. Kyiv: Verkhovna Rada of Ukraine. (Editorial series "The Law of Ukraine”). Available at: https://zakon.rada.gov.ua/laws/show/1618-15\#Text (accessed 22 March 2021).

11. Ukhvala u spravi № 686/29748/20 [2020] Hmel'nic'kogo mis'krajonnogo sudu Hmel'nic'koï oblasti. [Decision in the case No. 686/29748/20 [2020] of the Khmelnytsky City District Court of Khmelnytsky Region]. Yedynyi derzhavnyi 
reiestr sudovykh rishen. [United state register of court decisions]. Available at: https://reyestr.court.gov.ua/ Review/95125752 (accessed 28 March 2021).

12. Ukhvala u spravi № 548/136/21 [2021] Horol's'kogo rajonnogo sudu Poltavs'koï oblasti [Decision in the case No. 548/136/21 [2021] of the Khorol district court of Poltava region]. Yedynyi derzhavnyi reiestr sudovykh rishen. [United state register of court decisions]. Available at: https://reyestr.court.gov.ua/Review/95444558 (accessed 28 March 2021).

13. Ukhvala u spravi № 208/1496/21 [2021] Zavods'kogo rajonnogo sudu mista Dniprodzerzhins'ka Dnipropetrovs'koï oblasti. [Decision in the case No. 208/1496/21 [2021] of the Factory District Court of Dniprodzerzhynsk of Dnipropetrovsk region]. Yedynyi derzhavnyi reiestr sudovykh rishen [United state register of court decisions]. Available at: https://reyestr.court.gov.ua/Review/95463078 (accessed 28 March 2021). 